\title{
Kreatywność osób dojrzałych i czynniki sprzyjające jej wzbudzaniu
}

DOI: $10.47050 / 65591876.50-63$

Grażyna Bartkowiak

Przedmiotem rozdziału jest problematyka kreatywności osób dojrzałych. W pierwszej części, po ustaleniu definicji kreatywności, autorka analizuje psychologiczne uwarunkowania zachowań kreatywnych, rozpatrując zjawisko jako kategorię podmiotową, a więc charakteryzującą osoby o określonych cechach osobowości, i wskazując na mechanizm zachowań kreatywnych. W dalszej części została omówiona specyfika funkcjonowania osób w wieku dojrzałym w kontekście ich życia, a następnie kreatywność w odniesieniu do osób dojrzałych. W ostatniej części poruszono zagadnienia możliwości stymulowania kreatywnego myślenia u seniorów z perspektywy poszczególnych psychologicznych koncepcji człowieka, a także w perspektywie systemowej, wymagającej wprowadzenia określonych rozwiązań w praktyce dnia codziennego.

\section{Słowa kluczowe:}

kreatywność osób dojrzałych

stymulowanie kreatywności 


\section{Creativity of elderly people and factors conducive to its stimulation}

DOI: $10.47050 / 65591876.50-63$

Grażyna Bartkowiak

The subject of the article's deliberations is the issue of creativity of elderly people. In the first part, after defining the definition of creativity, the authoress analyzes the psychological determinants of creative behavior, considering the phenomenon as a subjective category, thus characterizing people with specific personality characteristics and pointing to the "mechanism of creative behavior". The next part discusses the specificity of functioning of elderly people in the context of their lives, and then creativity in relation to elderly people. The last part of the article discusses the issues of the possibility of stimulating creative thinking in seniors from the point of view of individual psychological concepts of a human being, as well as in the systemic perspective, requiring the implementation of specific solutions of everyday practice.

\section{Keywords:}

creativity of elderly people

stimulation of creativity 


\section{Wprowadzenie}

Czynniki warunkujące kreatywność osób dojrzałych i możliwość jej stymulowania ${ }^{1}$ były już przedmiotem licznych opracowań, podejmowanych zarówno na gruncie literatury polskiej, jak i anglojęzycznej. Mimo to problematyka ta stale jeszcze wydaje się inspirująca i godna kolejnych analiz. Dzieje się tak, ponieważ dotyczy zagadnień szczególnie istotnych zarówno z perspektywy rozwoju indywidualnych biografii osób dojrzałych, jak i funkcjonowania systemu społeczno-gospodarczego, mającego na celu przeciwdziałanie wykluczeniu osób dojrzałych, tak by zagospodarować tkwiący w nich potencjał intelektualny i społeczny. Drugim powodem jest ranga kreatywności jako czynnika dynamizującego naszą cywilizację.

\section{Kreatywność - ustalenia definicyjne}

Kreatywne myślenie polega na podejmowaniu świadomych wysiłków zmierzających do poznawania i zrozumienia określonych zależności w otaczającej nas rzeczywistości, a także do rozwiązywania problemów i kierowania sobą. W rezultacie chodzi o analizowanie i diagnozowanie rzeczywistości, a w konsekwencji o przewidywanie i planowanie oraz podejmowanie działań zmierzających do osiągnięcia zamierzonych, często ambitnych celów.

Ken Robinson i Lou Aronika (2009) uważają, że kreatywność polega nie tylko na twórczym rozwiązywaniu problemów, lecz także na ich dostrzeganiu i wynajdywaniu. Twierdzą, po pierwsze, że bycie kreatywnym wiąże się z działaniem, czyli z robieniem czegoś konkretnego a dodatkowo nowego. Ludzie nie są abstrakcyjnie kreatywni, stają się kreatywni dopiero podczas robienia czegoś praktycznego, np. w procesie rozwiązywania jakiegoś problemu, w projektowaniu, aktywnym uczestnictwie w kulturze, biznesie itp. Nie można być kreatywnym, jeżeli się czegoś nie robi, czyli $w$ tym aspekcie kreatywność, a więc twórcze myślenie, zasadniczo różni się od wyobraźni, marzeń czy wizualizacji (de Bono 2008). W odróżnieniu od tych ostatnich kreatywność polega nie tylko na wyobrażaniu sobie i tworzeniu nowych możliwości, lecz także na rozważaniu sposobów ich realizacji. W tym sensie kreatywność jest "stosowaną wyobraźnią" (Bieniok 2014, s. 48). 
W naukach społecznych wskazuje się na powiązanie (a niekiedy tożsamość) innowacyjności z twórczością² (Kozielecki 1992) i kreatywnością (Altszuller 1972; Altszuller 1983; Nęcka 1987, 1999; Nęcka, Orzechowski, Szymura 2017).

Psychologowie stosują też inny termin, który traktowany jest jako synonim kreatywności: jest to inwencja, "proces twórczy angażujący indywidualny, grupowy i organizacyjny potencjał kreatywności" (Kożusznik 2010a, s. 1; 2010b).

Pojęcie kreatywności jako działalności człowieka jest wieloznaczne, niemniej w literaturze przedmiotu można wyróżnić koncepcje, w których kładzie się nacisk na cechy psychiczne jednostki twórczej jako czynniki wywierające wpływ na jej aktywność twórczą (Sternberg, Lubbat za: Ulatowska 2013; Nęcka, Strzałecki, Trzebiński za: Tokarz 2010) oraz podejścia interakcyjne (np. Sawyer 2006; Simonton, Csíkszentmihályi, Kocowski za: Tokarz 2010), uwzględniające doniosłą rolę czynników społecznych i środowiskowych. Zgodnie z pierwszym podejściem twórczość definiuje się jako „działalność człowieka przynoszącą rezultaty obiektywne lub/i systematycznie wartościowe, we wszystkich dziedzinach życia, zwłaszcza w nauce sztuce i kulturze" (Tokarz 1998, s. 60-70). Drugie z wymienionych ujęć w większym stopniu koncentruje się na rezultatach i na przedmiocie ludzkiej działalności. W tym rozumieniu za "twórczy” można uznać nowatorski produkt, który osiąga taki poziom w opinii społecznej (Sawyer 2006, s. 27 za: Alcenar 2012, s. 88).

Csíkszentmihályi zwraca uwagę na to, że kreatywność jest swoistym odbiciem systemu społecznego, który dokonuje oceny jednostek. Tak więc, społeczne i kulturowe warunki w interakcji z indywidualnymi możliwościami decydują o tym, „że obiekty i zachowania są określone mianem twórczych" (Csíkszentmihályi 1994 za: Alcenar 2012, s. 88).

\section{Kreatywność na poziomie mechanizmów psychologicznych}

Z przeprowadzonych dotychczas badań wynika, że poziom inteligencji jest czynnikiem determinującym kreatywne myślenie. Ponadto (zgodnie z wynikami badania IPAR) osoby twórcze cechują się otwartością na wieloznaczność, a także niezależnością. 
Za znaczący czynnik w psychologii twórczości uważa się również Witkinowską "niezależność od pola", ujmowaną jako styl poznawczy. Twórca tej koncepcji potraktował ją jako właściwość, dyspozycję psychologiczną pozwalającą jednostce uniezależnić się od wyuczonych, narzuconych schematów myślenia i dzięki nowemu całościowemu spojrzeniu na problem znaleźć zupełnie inną konfigurację elementów, które mają związek z wytworzeniem nowej jakości. Według Witkina ludzie niezależni od pola wykazują większą skłonność do kreatywnego, oryginalnego ujmowania elementów rzeczywistości (za: Lewicki 1969; Trzebiński 1975). Posiadając wspomnianą właściwość, można łatwiej doznać zjawiska znanego w psychologii twórczości jako „insight". Polega ono na nowym, spontanicznym ujęciu elementów zewnętrznego i wewnętrznego pola spostrzeżeniowego (jego mentalnej reprezentacji). To nowe spojrzenie nagle staje się spójne i pozwala rozwikłać wiele - dotychczas nie do końca jasnych -zależności. Mimo że rozwój tej właściwości nie stał się zasadniczym przedmiotem zainteresowania autora, nie wykluczył on zasadności podejmowania działań w kierunku doskonalenia tej cechy (a być może i kompetencji). Czynnik ten zdaniem autorki można wiązać z "wewnętrzną sterownością" (za: Krasowicz, Kurzyp-Wojnarowska 1990).

Kolejną właściwością dość szeroko rozważaną w literaturze przedmiotu jest refleksyjność, ujmowana jako zdolność zachowania dystansu emocjonalnego wobec otaczających zjawisk, zdarzeń, własnych emocji i zaangażowania w określoną działalność (Brav i in. 2009). Kształtowanie refleksyjności przekłada się w programach szkolenia na ćwiczenie narracji jako metody rozwijającej autorefleksję, a także zdolność definiowania i oceny własnego stanowiska wobec prezentowanych treści.

W budowaniu poczucia sprawczości istotną rolę odgrywa także struktura zwana systemem "Ja". Jest on określany jako "dynamiczny i uporządkowany układ myśli, uczuć i motywów odnoszących się do własnych relacji społecznych i osobistego stosunku do świata" (Holye 2006 za: Strelau, Doliński 2010, s. 738). Obejmuje on następujące elementy (Heatherton i in. 2007):

$\rightarrow$ Ja poznawcze - samowiedzę,

$\rightarrow$ Ja wartościujące - samoocenę,

$\rightarrow$ Ja wykonawcze - autoregulację.

Dwa pierwsze elementy charakteryzują strukturę Ja, ostatni odnosi się do Ja ujmowanego jako proces. 
Czynnikiem warunkującym kreatywne myślenie okazały się jeszcze inne aspekty Ja, określające stosunek człowieka do wymogów otoczenia w kontekście własnych, świadomych motywów działania, jednak umożliwiających nabycie przez niego dystansu do własnych, uzależniających go potrzeb. Kazimierz Obuchowski stosunkowo wcześnie wyodrębnił Ja przedmiotowe oraz Ja intencjonalne (podmiotowe). Zdaniem tego autora Ja przedmiotowe jest "fenomenologicznie wtórne wobec Ja podmiotowego" (Obuchowski 2003, s. 162-177) i funkcjonuje jako pozwalające się człowiekowi zdystansować od jego bezpośrednich potrzeb i pragnień. Pozwala nawet nie poddawać się oddziaływaniu czynników zewnętrznych w obszarze działania, w którym funkcjonuje (np. wynikających z uwarunkowań kulturowych - przyp. autora). Ja przedmiotowe, stanowiące o treści i strukturze systemu Ja, poddane jest kontroli Ja intencjonalnego. W ten sposób możemy mówić o autonomii jednostki (Obuchowski 2000, s. 320.) dotyczącej własnych aspiracji, wizji własnej kariery czy sukcesu zawodowego niezależnie od wieku, który w tym przypadku jest czynnikiem zewnętrznym.

Ja podmiotowe obejmuje dwa procesy: autorefleksję, jako zdolność do samopoznania i ujmowania siebie w relacji do otoczenia, oraz samoregulację, jako funkcję wykonawczą, polegającą na umiejętności sprawowania kontroli nad własnymi myślami, uczuciami i działaniami (McDonald 2007 za: Oleś, Drat-Ruszczak 2010, s. 712).

Podobnie jak dzieje się w przypadku poznawania świata, wiedzę o sobie ujmujemy w formę określonych schematów Ja, np. przeświadczenia o własnej niezależności. Schematy te stają się elementem standardów, które z kolei wchodzą w skład Ja realnego, idealnego czy powinnościowego.

Istnienie Ja idealnego, zgodnie z koncepcją Charlesa Carveya (2001), sprawia, że u człowieka pojawia się system dążeń motywujących do osiągania swoich ideałów w poszczególnych obszarach życia. Z tego też względu rozbieżność między Ja realnym a Ja idealnym utożsamianym z Ja powinnościowym (wykreowanym w procesie socjalizacji) wywołuje zróżnicowane stany emocjonalne ${ }^{3}$. W przypadku realizacji standardów przez E. Tory Higginsa (Higgins 1987, 1996), w myśl założeń której duża rozbieżność między Ja idealnym a Ja realnym generuje stany emocjonalne takie jak depresja, smutek i przygnębienie, natomiast dużej rozbieżności między Ja realnym a Ja powinnościowym towarzyszy lęk strach przed karą, poczucie winy. 
Ja idealnego wzrasta poczucie satysfakcji, spełniania się, a nawet radości, jakże istotne w przypadku osób dojrzałych.

W niniejszym opracowaniu kreatywność utożsamiana jest ze zdolnością do wprowadzania nowych rozwiązań, odkrywania nowych, skutecznych metod, w wyniku pojawienia się w umysłach ludzi nowych oryginalnych pomysłów, które w konsekwencji przyczyniają się do podwyższania jakości życia człowieka.

\section{Ludzie w wieku dojrzałym}

Starzenie się jako proces i starość jako kulturowo kształtowane zjawisko niosą ze sobą pewnego rodzaju opresyjność. Nie tylko dlatego, że starość to ostatni okres w życiu, który kończy się śmiercią, ale też z powodu zmian wartości, które dokonują się w biografii seniorów, oraz struktury życia społecznego i tempa zachodzących w nim przeobrażeń, mających strategiczne znaczenie dla jednostkowego funkcjonowania ludzi starych i dla ich tożsamości (Chabior 2017, s. 7-8). Starość określa się jako okres w życiu organizmu nieuchronnie występujący po okresie dojrzałości i cechujący się istotnymi zmianami w narządach i tkankach.

Starość współtowarzyszy niemal wszystkim procesom społecznym. Nie zawsze jednak stanowi etap wypełniony radością, spokojem, poczuciem satysfakcji. Wszechobecny rozwój technologiczny nie tylko zagwarantował pozytywne zmiany, lecz także wygenerował nowe zagrożenia i problemy. Mimo że osoby starsze stanowią grupę bardzo zróżnicowaną ze względu na sytuację osobistą, rodzinną, zawodową, zdrowotną i materialną, społeczeństwo zdaje się o tym zapominać, budując niewłaściwe przekonanie na temat seniorów i starości (Dubas, Muszyński 2016, s. 115).

Jakość życia w okresie starości jest wyznaczana przez wiele powiązanych wzajemnie czynników, wśród których ważne miejsce przypisuje się zdrowiu, aktywnej postawie wobec życia. Początkowo pojęcie „jakość życia" bazowało na ekonomicznym wymiarze egzystencji człowieka. Zakładano, że jest to zależność liniowa o kierunku dodatnim, wraz z wyższym dochodem i materialnym poziomem życia osiąga się wyższą jego jakość. Współcześnie włącza się w zakres tego pojęcia także aspekt psychologiczny i społeczny, w tym dobrą pozycję społeczną, poczucie stabilizacji życiowej, podejście do życia, umiejętność rozwiązywania problemów. Szczególne znaczenie przypisuje się zdrowiu jako podstawie całościowego funkcjonowania człowieka. Pojęcie 
"jakość życia" jest konstruktem wielowymiarowym, kształtowanym przez czynniki zarówno obiektywne, jak i subiektywne. Postrzegana subiektywnie jakość życia odzwierciedla poziom zadowolenia z życia w jego zdrowotnym, materialnym i duchowym wymiarze. Zgodnie z koncepcją WHO jakość życia to postrzegana przez jednostkę pozycja w życiu, w kontekście kultury i systemu wartości, w których żyje, oraz w zgodności z własnymi celami, oczekiwaniami, standardami i obawami (Halicka, Halicki, Kramkowska 2016, s. 325-327). Definicja ta opiera się na wcześniejszej definicji zdrowia, zgodnie z którą jest ono stanem fizycznego, psychicznego i społecznego dobrostanu, a nie tylko brakiem choroby czy ułomności (Definicja...).

Definicja ta stanowi podstawę do wykreowania nowej koncepcji medycyny, w której naukę tę czyni się odpowiedzialną nie tylko za przedłużenie biologicznego życia człowieka, ale również za usprawnienie go i uczynienie bardziej aktywnym.

Istnieje jednak wiele definicji jakości życia. Jest to pojęcie wielowymiarowe zmieniające się w czasie, definiowane nieco odmiennie na gruncie różnych nauk. W koncepcjach filozoficznych jakość życia utożsamiana jest $z$ dobrostanem (well-being), określanym jako różnica między "sumą wszystkich rodzajów przyjemności" a "sumą wszystkich rodzajów cierpień", jakich człowiek doświadcza w określonym przedziale życia.

Jakość życia bywa utożsamiana z dobrostanem, satysfakcją, szczęściem, dobrym życiem. Może być zaś mierzona stopniem, w jakim ludzie cieszą się życiem, wyrażają radość i satysfakcję z niego.

Jakość życia próbuje się poszerzyć w ostatnim czasie o wymiar duchowy, obejmujący wiarę religijną i przekonania światopoglądowe. W ocenie jakości życia istotną rolę odgrywają zasoby psychospołeczne, zarówno zdobyte we wcześniejszych okresach, jak i aktualne zasady i sieci wsparcia. Wcześniej koncepcja jakości życia w odniesieniu do seniorów opierała się na modelu patologii i zależności, koncentrowała się na pomiarze obniżonej wraz z wiekiem sprawności fizycznej, narządów zmysłów oraz na ograniczeniach w czynnościach. Obecna koncepcja jakości życia uwarunkowana stanem zdrowia jest ukierunkowana na pozytywne aspekty wskazujące na możliwość samodzielnego funkcjonowania osoby dojrzałej również w sytuacji, kiedy doświadcza ona niepełnosprawności czy przewlekłej choroby. Te możliwości funkcjonowania zależą od wielu czynników, od zasobów materialnych i sieci 
społecznych zbudowanych w toku całego dotychczasowego życia oraz ogólnego poczucia satysfakcji życiowej. Na gruncie nauk medycznych oznaczało to przyjęcie szerszej perspektywy wykraczającej poza tradycyjne koncepcje zdrowia (Halicka, Halicki, Kramkowska 2016, s. 325-327).

W aktualnych koncepcjach jakości życia uwzględnienie roli realizacji własnych pasji, wcześniej rozwiniętych zainteresowań wśród osób dojrzałych jako niezbędnych przesłanek kreatywnego nastawienia do życia nabiera szczególnego znaczenia. Chodzi o możliwość korzystania z rezerwuaru własnych zasobów, niezależnie od ograniczeń fizjologicznych, które pojawiają się w zróżnicowanym nasileniu, motywujących do dalszej aktywności i nadających sens własnemu życiu.

\section{Kreatywne myślenie u osób dojrzałych}

Jest prawdą oczywistą, że kreatywne myślenie współwystępuje z inteligencją ogólną, choć nie jest z nią tożsame. Jeśli niezależnie od istniejących kontrowersji za myślenie kreatywne uznajemy działania z jednej strony nowatorskie, z drugiej zaś użyteczne, badania przeprowadzane za pomocą testów kreatywności wykazały, że ludzie dojrzali słabiej wypadają w badaniach dotyczących myślenia dywergencyjnego (Stuart-Hamilton 2006, s. 78). Sytuacja ta zdaniem autora może być konsekwencją pewnego niewielkiego "ubożenia zdolności intelektualnych". Jednak zaistniała rozbieżność występuje, jeśli dokonuje się porównania osób młodszych ze starszymi, o tym samym poziomie intelektualnym i niezbyt wysokim wykształceniu (Alpaugh, Birren 1977; Mc Crae, Arenberg, Costa 1987). Wśród osób, które całe życie pozostawały zaangażowane w określoną działalność, różnica ta może być zdecydowanie mniejsza, a nawet może nie występować wcale (Crosson, Robertson-Tchabo za: Stuart-Hamilton 2006, s. 78-79).

Do ciekawych wniosków doszła Jennifer Sasser-Coen (1993), deprecjonując myślenie dywergencyjne w myśleniu twórczym na rzecz osobistego doświadczenia, dzięki któremu osoba dojrzała generuje pomysły. Mimo to niezależnie od osiągniętych w badaniach rezultatów Dean Simonton (1990) i Jon Hendricks (1999) podali w wątpliwość zasadność badania osób starszych miarami psychometrycznymi jako trafnymi predykatorami kreatywności w "prawdziwym życiu”.

Istnieją też dowody, że zaangażowane twórcze działanie osób starszych jest czynnikiem podnoszącym ogólną samowiedzę i samoocenę, 
zwiększającym poczucie dobrostanu (Hickson, Housley 1997 za: Stuart-Hamilton 2006; Steuden 2012).

Ustosunkowując się do niezależności w myśleniu i uniezależnienia się od zewnętrznych nacisków, badacze utożsamiali je z mądrością ludzi dojrzałych.

Podobnie jak w przypadku innych omawianych pojęć, mimo że mądrość (istota pojęcia, jej pomiar) wzbudza kontrowersje, Paul Bales i Jacqui Smith (2008) używają określeń „roztropność" i "dalekowzroczność w dokonywaniu sądów" niezależnych od ocen zewnętrznych, prezentujących dystans w planowaniu przyszłości przez osoby dojrzałe.

Na niezależność w formułowaniu własnych sądów i opinii u osób dojrzałych zwracali uwagę Ursula Staudinger, David Lopez i Paul Baltes (1997) oraz Staudinger i in. (1998), a także Wilson (2013). Jest to w rozumieniu tych autorów znacząca cecha, która świadczy o osobowości i inteligencji osób starszych (w porównaniu do ludzi młodszych), chociaż nie jest z nimi tożsama.

Z kolei efektywna samoregulacja i przekonanie o własnej skuteczności osób dojrzałych zostały przez Chandlera i Hollidaya (1990) ujęte jako poczucie kompetencji i realna zdolność do skutecznego rozwiązywania problemów, w których ważną rolę odgrywa czysta logika, typowy atrybut okresu późnej dorosłości.

Inny wątek badań nad kreatywnością osób dojrzałych dotyczy analizy biografii twórców. Jednak jego rezultaty nie są jednoznaczne, nie pozwalają bowiem ani na odrzucenie tezy, że myślenie kreatywne nie występuje w wieku późnej dorosłości, ani też na jej potwierdzenie. Przykładowo przywołany już Simonton (1990) jest zdania, że osoba kreatywna w poszczególnych okresach swojego życia niezależnie od wieku tworzy tyle samo przeciętnych prac, co prac nieprzeciętnych. Pnina Ron (2007) z kolei optuje za tym, że dla większości ludzi kreatywne działanie kończy się przed osiągnięciem 60. roku życia. Przyczyną tej sytuacji jest ograniczenie i pogorszenie się sensoryki i wydolności fizycznej człowieka dojrzałego, a do twórczego działania wierny i rzetelny ogląd rzeczywistości wydaje się niezbędny. Przeciwstawny pogląd prezentuje Butler (1967 za: Bartkowiak, 2016, s. 94), odwołując się do kazusów twórców, np. Tyego, którego dzieła namalowane po 90. roku życia są uznawane za najbardziej wartościowe, czy Beethovena, który w późniejszym okresie życia stracił słuch a dla którego ten deficyt stał się źródłem dalszych inspiracji. 
Wyjaśnienie zaprezentowanych kontrowersji wydaje się równie złożone, co obarczone błędami oceny, zgodnie z przytoczoną wcześniej definicją twórczego działania. Chodzi o społeczny kontekst osiągnięć uznanych za twórcze (Holroyd i in. 2009). Może on okazać się czynnikiem kontrowersyjnym, ponieważ może obejmować nie tylko elementy działań nie tyle twórczych, ile związanych z administracyjnie pełnioną funkcją.

Reasumując, zmiany w poziomie kreatywności w ciągu życia mogą wynikać bardziej ze stylu życia, społecznych wymogów wykonywanego dotąd zawodu niż z procesu starzenia się jako cyklu postępujących zmian fizjologicznych.

\section{Możliwości stymulowania kreatywności osób dojrzałych}

Wśród możliwości stymulowania kreatywności można wyróżnić podejścia psychologiczne i systemowe.

Analizując podejścia psychologiczne, wyodrębniono podejście behawiorystyczne, humanistyczne, poznawcze oraz oparte na założeniach psychologii pozytywnej. W pierwszym z nich istotną rolę w rozwiązywaniu problemów związanych z twórczym myśleniem odgrywa wspierające i inspirujące oddziaływanie środowiska. Kreatywność w tym rozumieniu pojawia się jako efekt działań zmierzających do przekształcania rzeczywistości na podstawie posiadanej wiedzy, nabytych kompetencji i wzbudzanej przez otoczenie motywacji do działania. Psychologia humanistyczna interpretuje człowieka jako podmiot autonomiczny, który obserwuje, przewiduje, planuje, wnioskuje i który-zgodnie z posiadaną wiedzą - przystosowuje się do świata, kształtuje go. W ramach koncepcji humanistycznej istotną rolę odgrywa omówiona już wcześniej refleksyjność (Brav i in. 2009). Kształtowanie refleksyjności prowadzącej do kreatywnego myślenia (Trzebińska 2008, s. 141) przekłada się w programach szkolenia pracowników na ćwiczenie narracji jako metody rozwijającej autorefleksję, a także zdolność zdefiniowania i oceny własnego stanowiska wobec prezentowanych treści.

Przedstawiciele koncepcji poznawczej dużą wagę przywiązują do twórczości człowieka. Mimo że w obrębie jej założeń człowiek jest jednocześnie układem wartościującym i samosterującym się, w myśl założeń tej koncepcji szczególnie istotną rolę odgrywają treningi twórczości, które na każdym etapie życia człowieka czynią ludzkie myślenie bardziej elastycznym i przyczyniają się do wykreowania sprzyjających myśleniu twórczemu określonych struktur poznawczych. Struktury te 
z kolei pozwalają człowiekowi na redukowanie rozbieżności między Ja realnym a Ja idealnym.

Psychologia pozytywna dużą wagę przykłada do działań zwiększających dobrostan człowieka. Jako wywodząca się z psychologii humanistycznej podkreśla rolę poczucia sensu w pracy zawodowej jako warunku zaangażowania i twórczej postawy. Stymulacja do twórczego rozwoju w myśl założeń psychologii pozytywnej powinna rozbudzać nadzieję wśród osób dojrzałych na dalsze satysfakcjonujące życie (por. Trzebińska 2008, s. 150).

Prezentowane podejścia do twórczego działania człowieka, nawiązujące do określonych koncepcji psychologicznych, oczywiście nie wyczerpują wszystkich aktualnie funkcjonujących koncepcji, stanowią raczej wprawkę powiązania określonej psychologicznej koncepcji człowieka z jego kreatywnością.

Podejście systemowe zakłada, że praca twórcza jako szansa na kontynuację aktywności zawodowej osób dojrzałych, wymagająca wykorzystania nowych technologii, w tym automatyzacji i robotyzacji czynności powtarzalnych, prowadzi do zmniejszenia liczby miejsc pracy i wzrostu bezrobocia, ale też generuje nowe, bardziej elastyczne stanowiska (Król 2006 , s. 22-27). Stałe zatrudnienie staje się domeną branż wymagających najwyższych kwalifikacji. Zachodząca "dematerializacja pracy" (Marody, Giza-Poleszczuk 2004, s. 239-257), czyli jej łączenie z operowaniem abstraktami i ideami - zamiast bezpośredniego udziału ludzi w wydobywaniu i przetwarzaniu surowców czy wytwarzaniu dóbr i usług materialnych - w mniejszym stopniu wymaga wysiłku fizycznego.

Praca twórcza w znacznej mierze opiera się na wykorzystaniu technologii cyfrowych, realizacji zadań nieokreślonych, zmiennych i refleksyjnych oraz na samodzielności, kwestionowaniu norm, tradycji i przepisów, a także kończy się niestandardowymi efektami (Schulz 1990, s. 155-156; Filiciak, Tarkowski 2010, s. 81-82). Wychodząc z takiego założenia, można uznać, że zachodzące w gospodarce, technologii i ekonomii zmiany sprzyjają twórczemu zaangażowaniu seniorów, w szczególności dysponujących użytecznymi zasobami, tzn. wiedzą niekonwencjonalną i oryginalnością, które stają się kluczowym zasobem pracowników. Posiadanie wiedzy jako istotnego zasobu pozwala na dłuższe pozostawanie zatrudnionym w pracy dzięki postrzeganiu jej w kategoriach rozwoju osobowości czy samorealizacji (por. Schulz 1990, s. 163-164; Marody, Lewicki 2010, s. 125; Jung 2009). 
W krajach wysokorozwiniętych praca twórcza uzasadnia próby utrzymywania osób dojrzałych jak najdłużej na rynku pracy, by ograniczyć obciążenia w systemach emerytalnych. Relacje między pracą a czasem wolnym seniorów pozwalają przypuszczać, że kreatywność może służyć łagodzeniu niekorzystnych skutków przejścia na emeryturę, ograniczaniu negatywnych stereotypów dotyczących starości oraz poszukiwaniu nowych ról społecznych dla seniorów.

W tym kontekście zdaniem Andrzeja Klimczuka (2013) możliwe jest podjęcie próby stworzenia podziału na klasę kreatywną i usługową. W pierwszym przypadku mielibyśmy do czynienia z seniorami kreatywnymi podejmującymi aktywność twórczą na rozmaitych polach: kultury, sztuki i nauki oraz przyjmującymi role animatorów, artystów i badaczy (za: Leszczyńska-Rejchert 2007, s. 205; Wawrzyniak 2010, s. 19-20; Dzięgielewska 2006a, s. 163-164). Działania te mogą prowadzić do poprawy stanu zdrowia, zapominania o wadach starości oraz do poszukiwania gerontechnologii ułatwiających życie. Osoby te będą przypuszczalnie częściej odmładzać się, podważać istnienie wieku emerytalnego, kontynuować aktywność zawodową, rozpoczynać nową karierę lub zakładać własne przedsiębiorstwa (Giddens 2009, s. 92, 170-176). Z drugiej strony "seniorzy usługowi" reprezentowaliby zbiór osób, które na ostatnim etapie życia w mniejszym lub większym stopniu pomagają innym w osiąganiu ich celów. Mieściłyby się tu osoby wspomagające emeryturami swoje rodziny, wspólnoty religijne i grupy samopomocowe. Jednakże badania sondażowe przeprowadzone przez autorkę wśród 257 studentów z trzech uczelni kierunków humanistycznych i społecznych w trzech dużych miastach w Polsce dotyczące prospołecznego nastawienia i chęci niesienia pomocy przez ich babcie i dziadków w $97 \%$ wykazały prospołeczne nastawienie wyłącznie w odniesieniu do własnej rodziny.

W każdym przypadku wspomaganie aktywnej postawy osób dojrzałych wymaga tworzenia odpowiednich warunków, rozwiązań systemowych dla seniorów, uwzględniających specyfikę wieku dojrzałego (wyraźne napisy ulic, telefony komórkowe z powiększoną klawiaturą), sieć usług ułatwiających codzienne funkcjonowanie (np. zakupy z wniesieniem do domu, windy w większości miejsc zamieszkania, bardziej dostępna opieka zdrowotna itp.). Wówczas energię seniorów będzie można spożytkować na kreatywne myślenie czy też aktywne uczestnictwo w życiu społecznym, dłuższe zatrudnienie, świadomą 
organizację czasu wolnego połączoną z uczestnictwem w szeroko pojmowanej kulturze.

\section{Zamiast zakończenia}

Przeprowadzone rozważania wskazały na złożoność omawianej problematyki: zróżnicowanie w obrębie samego rozumienia pojęcia i wielość uwarunkowań działania kreatywnego. Jednocześnie jego systemowy charakter wymaga podjęcia licznych działań, zarówno na poziomie indywidualnym, w odniesieniu do systemu edukacji, pracy zawodowej, jak i w szerszym rozumieniu, odnoszącym się do uwarunkowań systemowych: społeczno-ekonomicznych.

Aplikacyjny charakter wniosków płynących z rozważań o kreatywności wymaga uprzedniego analitycznego podejścia do problemu, poznania specyfiki ich funkcjonowania i rozpoznania mechanizmów regulacji zachowania osób w wieku senioralnym. 